\title{
HENRY D. GINSBURG
}

$$
(1940-2007)
$$

Henry Ginsburg, who died in New York on 29 March 2007, was for over thirty years curator of the Thai, Lao and Cambodian collections in the British Museum and the British Library, and an eminent authority on Thai manuscript painting, a field he largely made his own.

Henry David Ginsburg was born in New York on 5 November I940 to parents who were both antique dealers, and from whom he inherited a life-long appreciation of and sympathy for fine art. He studied French literature at Columbia University and then served in the Peace Corps in Thailand from I964 to I966, an experience which set the course of the rest of his life. In 1967 he moved to London and commenced doctoral studies in Thai literature under Stuart Simmonds at the School of Oriental and African Studies, London, obtaining his Ph.D. in I97I.

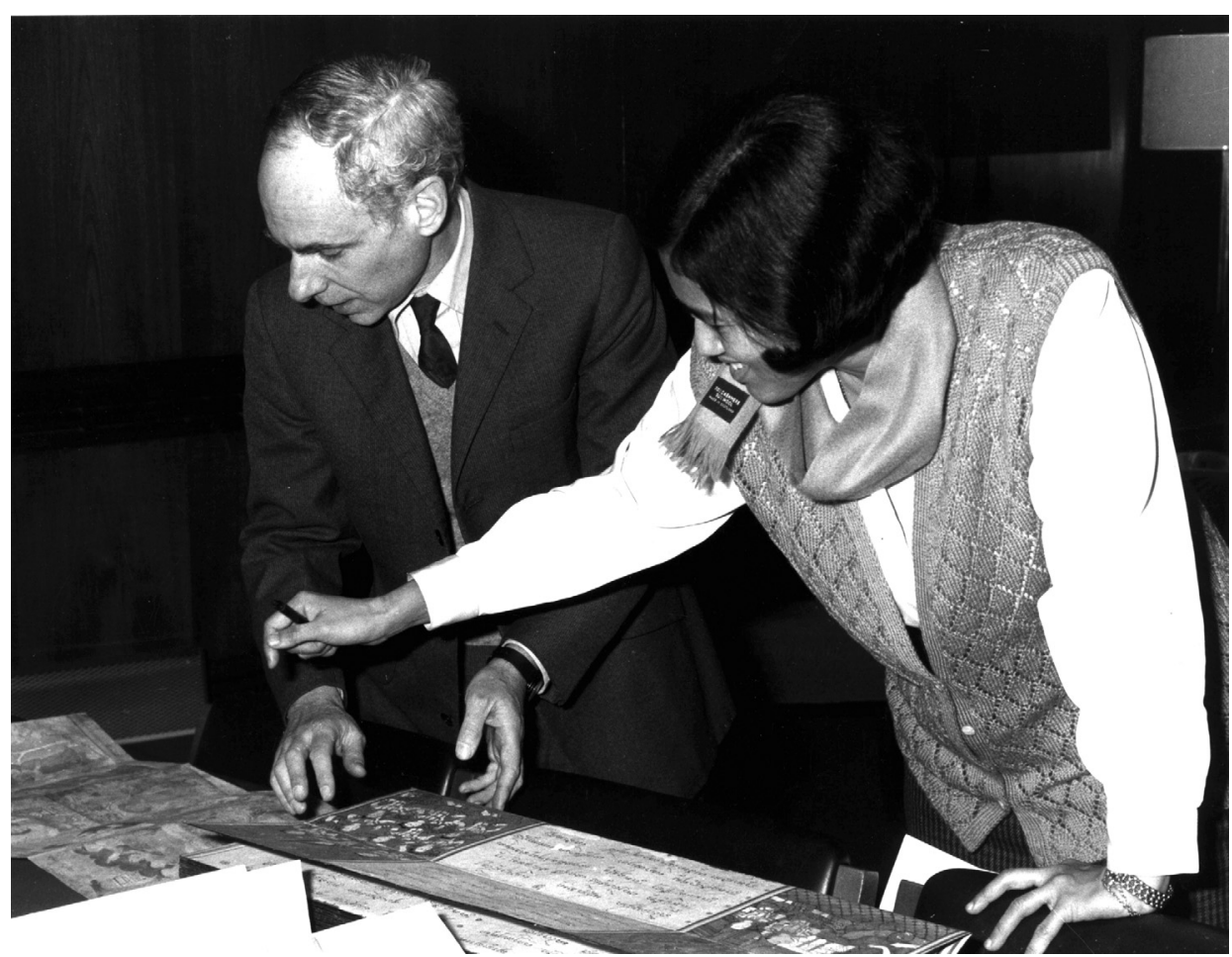

Fig. I. Henry Ginsburg showing some manuscripts to Her Royal Highness Princess Maha Chakri Sirindhorn of Thailand during a visit to the British Library on I6 January I99I. 
Later that year Henry joined the British Museum as a Special Assistant responsible for the Thai collections, and with other staff in the Department of Oriental Manuscripts and Printed Books (OMPB) he moved to the newly-formed British Library in I973. For the next three decades Henry remained a part-time member of staff, successfully resisting all attempts by central administration to regularise his hours; the flexibility suited him and enabled him to travel and pursue numerous other interests. Even official retirement in 2003 saw little change to his routine, as he continued to appear in the Library on most days to work on various Thai manuscript projects.

When Henry joined the British Museum library, the Southeast Asia collections very much reflected British imperial engagement with the region. The richest collections of manuscripts and early printed books were from countries formerly under British colonial administration such as Burma, Malaysia and Singapore, and even from Java, briefly under British rule from I 8 I I to I 8I6. Conversely, from regions where Britain had had little imperial involvement the Philippines, Vietnam, Laos, Cambodia and Thailand - collections were relatively thin. As highlighted by Graham Shaw - head of the Asia, Pacific and Africa Collections, successor to OMPB - in an address at Henry's memorial service in London on I 5 June 2007, Henry's unique achievement at the British Library was to build up, slowly and steadily, by discerning acquisition (and within all the constraints of the age), one of the finest collections of illustrated Thai manuscripts in the world.

Thus every year the accession registers for oriental manuscripts show a handful of choice acquisitions, usually of the genres of Thai manuscripts most likely to be illustrated, such as the tale of the monk Phra Malai, the ten birth tales of the Buddha, divination and astrological works, and elephant treatises. Sometimes considerable detective work was involved, as when Henry successfully tracked down paintings which had been removed from an elephant treatise before it was acquired by the British Library (Or. 13652). Occasionally there was the opportunity to buy very rare material, such as in 1983 , when eight drawings by the Thai artist Bun Khong commissioned by Captain James Low were acquired (Or. I4I79), to complement the album of drawings by Bun Khong for Low already held in the British Library (Add. 27370). Low was the British envoy to the state of Nakhon Sithammarat in I 824, and these are the only known Thai examples of the Company School of painting, that is, paintings commissioned from local artists by officials of the East India Company. Another more unusual acquisition was of two gilt wood inscribed title indicators for Northern Thai religious texts (Or. I4528 \& Or. I4529) in I990.

A foretaste of the formidable artistic and intellectual project that Henry had embarked on was revealed in a small exhibition held in the British Library from January to November I983 on Thai illustrated manuscripts, which included six of the Bun Khong drawings for Low, as well as a number of traditional folding book manuscripts. Two years later, together with other colleagues in OMPB, Henry contributed to the joint British Museum-British Library exhibition, Buddhism: art and faith; he wrote the introduction to the chapter on Thailand and Cambodia in the exhibition catalogue. All this paved the way for his book on Thai manuscript painting, published in 1989 - the first major monograph on the subject. Illustrated manuscripts were discussed in terms of their subject matter, followed by studies of genre painting and developments in style, and an important appendix listing Thai illustrated manuscripts in western collections. (Of the 36 illustrated manuscripts listed in the British Library, 28 had 
been acquired during Henry's stewardship of the collections.) The publication was marked by an exhibition in the King's Library from i6 February to I July I990.

In 1996 the Office of the National Culture Commission of Thailand invited the British Library to produce an exhibition of original and facsimile Thai manuscripts from the Library's collections to mark the Golden Jubilee of His Majesty King Bhumiphol and the state visit to Thailand of Her Majesty Queen Elizabeth II. The exhibition, which was held from 3 I October - 29 November 1996 at the Changing Exhibition Hall of the Thailand Cultural Centre, Bangkok, was officially opened by Her Majesty, accompanied by Her Royal Highness Princess Maha Chakri Sirindhorn. The success of this project owed much to the empathy between Henry and Her Royal Highness, who visited the British Library on several occasions. A lasting memento of the exhibition was the publication in 2000 of Henry's book Thai art and culture: historic manuscripts from Western collections, which included most of the exhibited works. In a very natural scholarly progression from his earlier book, in this work Thai illustrated manuscripts were presented alongside texts of literary or historical merit, and important foreign source materials on Thailand, including East India Company trading records and a unique seventeenth-century Persian account of an embassy to the court of King Narai (Or. 6942).

Henry's close friendship with another member of the Thai royal family, Princess Narisa Chakrabongse - daughter of Prince Chula and granddaughter of Prince Chakrabongse led to the generous donation to the British Library in 200I of the Chakrabongse Letters (Or. I 5749), a collection of some 200 letters from Prince Chakrabongse, his father King Chulalongkorn and his successor King Vajiravudh, to each other and to other family members. Through his personal and professional contacts, Henry was also responsible for another important gift to the British Library in 2004, of manuscripts and gilded manuscripts chests from Thailand and Burma from the Doris Duke Collection.

At the time of his death Henry was working on a catalogue of the Thai manuscripts in the Chester Beatty Library in Dublin, while continuing to catalogue the Chakrabongse letters. Throughout this period he was also graciously imparting his immense knowledge of the Thai books and manuscripts to his successor as curator, Jana Igunma, and still continuing to send to the Library important manuscripts which he felt should be added to the collection. He had brought in one such manuscript - a copy of the Phra Malai tale, in Cambodian Mul script with illustrations of a very high quality - for consideration shortly before his final visit to New York; it has now been acquired by the British Library in his memory (Or. I6552). From his estate, the Library has also received the donation of two fine gilded wooden title indicators (Or. I6554 \& Or. I6555).

Henry's sudden and unexpected death (from a heart problem) left ripples of shock and sadness across three continents - obituaries appeared in, amongst others, The Daily Telegraph and The Independent in London, Antiques and the Arts Online in New York, the Journal of the Siam Society in Bangkok, and in the Hong Kong-based journal Orientations. Henry had dedicated his book Thai art and culture to "the superb artists and scribes, nearly all anonymous, who created the life-enhancing works of art shown here, happily enduring memorials to the rich cultural heritage of old Thailand", but he himself should best be remembered for his unique role in enhancing lives by preserving, documenting and interpreting these exquisite works of art, and greatly raising their public profile in Thailand and beyond. 


\section{Henry D. Ginsburg: Bibliography}

\section{Books}

I97 I The Sudhana-Manoharā tale in Thai: a comparative study based on two texts from the National Library, Bangkok, and Wat Machimāwāt, Songkhla. Ph.D. thesis, School of Oriental and African Studies, University of London.

I989 Thai manuscript painting. London: British Library.

2000 Thai art and culture: historic manuscripts from western collections. London: British Library.

2006 Siam in trade and war: royal maps of the nineteenth century. Narisa Chakrabongse, Henry Ginsburg... [et al]. Bangkok: River Books.

\section{Journal Articles and Chapters in Books}

I972 The Manora dance-drama: an introduction. Journal of the Siam Society, Vol. 6o, Pt. 2 (July I972), pp. I69-I8 I.

I975 The Thai tales of Nang Tantrai and the Pisaca tales. Journal of the Siam Society, Vol. 63, Pt. 2 (July I975), pp. 279-3 I4.

I985 Low in Thailand. FMR, I3, July I985, p. I25.

I985 Thailand and Cambodia. Buddhism: art and faith. Edited by W. Zwalf. London: British Museum Publications, pp. I75-I76.

I987 The Sudhana-Manoharā tale in Thai. Lāi Sü' Thai: essays in honour of E.H.S. Simmonds. Edited by Jeremy H.C.S. Davidson. London: School of Oriental and African Studies, University of London, pp. I I6-I28.

I99I BL's royal guest. OIOC Newsletter, No. 46 (Spring/Summer I99I), p. I9.

1993 Elephant manuscript restoration progresses. OIOC Newsletter, No. 48-49 (Autumn I993), p. I8. [A short note on the 'reunification' of illustrations from a Thai manuscript treatise on elephants in the British Library, Or. I3652.]

200 I Buddhas of the past in Southeast Asia. Buddha: radiant awakening. Edited by Jackie Menzies. Sydney: Art Gallery of New South Wales, pp. I 54-I 55.

2005 Ayutthaya painting. The Kingdom of Siam: the art of central Thailand, 1350-1800. Edited by Forrest McGill. Ghent: Snoeck Publishers; Bangkok: Buppha Press; Chicago: Art Media Resources; San Francisco: Asian Art Museum of San Francisco - Chong-Moon Lee Center for Asian Art and Culture, pp. 95-I09.

2006 Manuscript chests from Thailand and Burma; A royal Thai letter. A cabinet of oriental curiosities: an album for Graham Shaw from his colleagues. Edited by Annabel Teh Gallop. London: British Library, [nos.] 32-33.

2007 Thai painting in the Walters Art Museum. Journal of the Walters Art Museum, 64/65 (2006/2007), pp. I47-79. [Published posthumously.]

\section{Reviews}

I973 Review of: Ceramic art of Southeast Asia, William Willetts (Singapore: Southeast Asian Ceramic Society, I97I). Journal of the Siam Society, Vol. 6I, Pt. I (Jan. I973), pp. $38 \mathrm{I}-383$.

I973 Review of: Ten lives of the Buddha: Siamese temple paintings and Jataka tales, Elizabeth Wray, Clare Rosenfield and Dorothy Bailey (New York: Weatherhill, 1972). The Journal of Asian Studies, Vol. 32, No. 3 (May I973), pp. 559-56I. 
1974 Review of: Phra khamphī Thüpawong (Bangkok, 1968) and The chronicle of the Thupa and the Thupavamisa, N. A. Jayawickrama (editor and translator) (London: Luzac, for the Pali Text Society, I97I). Journal of the Siam Society, Vol. 62, Pt. I (Jan. I974), pp. $284-285$.

1974 Review of: Buddhist folk tales depicted ay Chula Pathon Cedi, Piriya Krairiksh (Bangkok, I974). Journal of the Siam Society, Vol. 62, Pt. 2 (July 1974), pp. 376-377.

I974 Review of: Monuments of the Buddha in Siam, Prince Damrong Rajanubhab (Bangkok: Siam Society, I973). Journal of the Siam Society, Vol. 62, Pt. 2 (July I974), pp. 378-379.

I974 Review of: Hindu gods of peninsular Siam, Stanley J. O’Connor, Jr. (Ascona: Artibus Asiae, I972). Oriental Art, New Series, Vol. 20, No. 3 (Autumn I974), p. 3 I 8.

I976 Review of: Nang talung, Suthiwong Phongphaibun (Bangkok, n.d.). Journal of the Siam Society, Vol. 64, Pt. I (Jan. I974), pp. 422-424.

I990 Review of: Thai and Cambodian sculpture, from the 6th to the 14th century, Martin Lerner and Wolfgang Felten (London: Philip Wilson, I989). Oriental art, I I, p. I47.

I99I New York and Washington: Indonesian art. The Burlington magazine, Vol. I33, No. I060 (July I99I), pp. 480-482. [A review of three major touring exhibitions: The sculpture of Indonesia, Court arts of Indonesia and Beyond the Java Sea.]

2005 Review of: Reading Thai Murals, David K. Wyatt (Chiang Mai: Silkworm, 2004). Online review, posted 22 March 2005, at http://www.caareviews.org/reviews/726.

\section{Reviews of Books by Henry D. Ginsburg}

I990 Brown, Robert L. Review of: Thai manuscript painting. In: Journal of Asian Culture, I4, pp. $90-92$.

I99I Guy, John. Review of: Thai manuscript painting. In: Orientations, Vol. 22, No. 3 (March I99I), pp. $73-76$.

200 I Raendchen, Jana. Review of: Thai art and culture: historic manuscripts from Western Collections. In: Tai Culture International Review on Tai Cultural Studies, Vol. 6 (200I), pp. $383-384$.

Annabel Teh Gallop

The British Library and The Royal Asiatic Society 


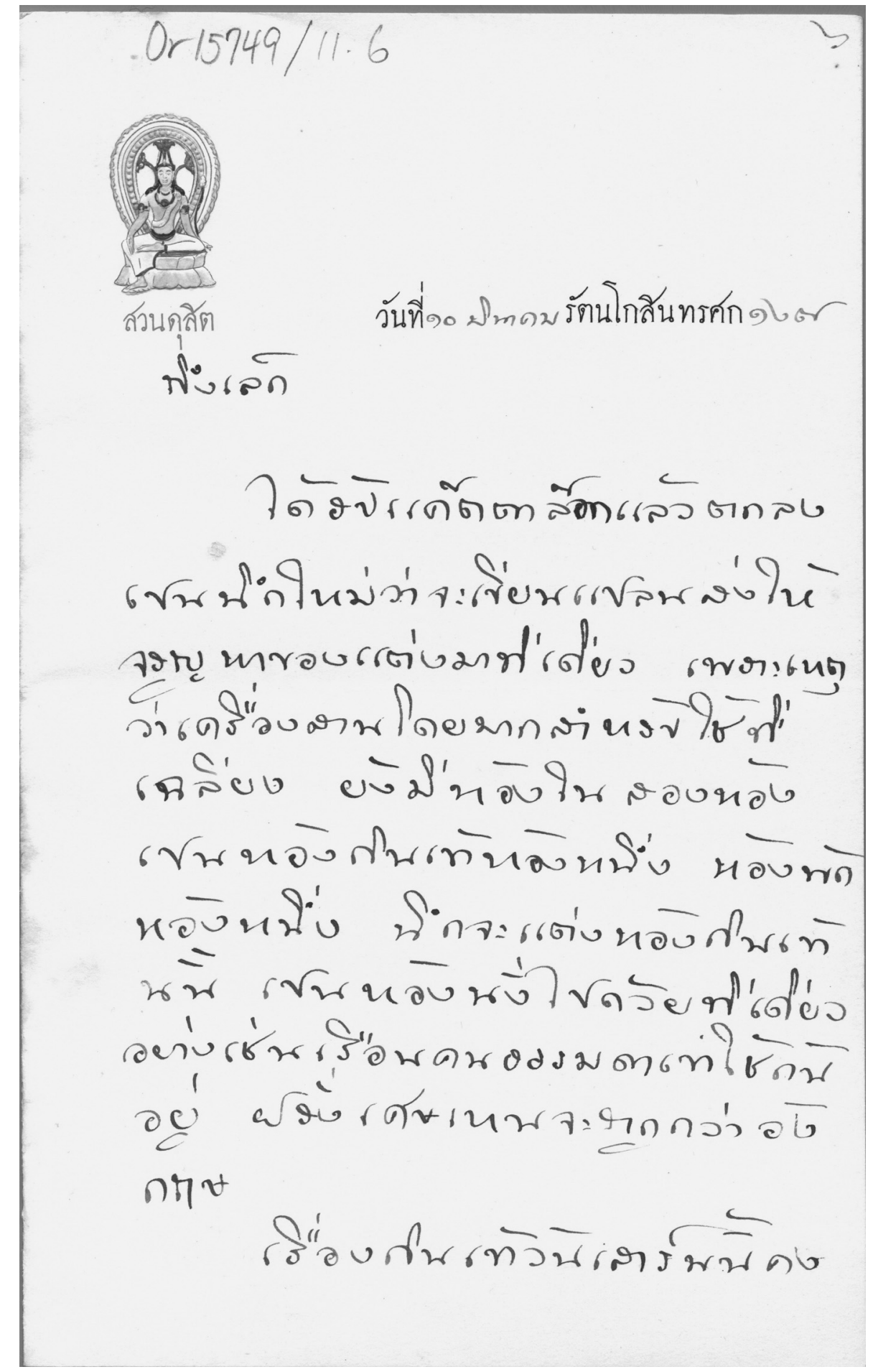

Fig. 2. A letter from King Chulalongkorn (Rama V) of Thailand to his favourite son Prince Chakrabongse, Io March I909; from the collection of royal letters donated to the British Library by Princess Narisa Chakrabongse, granddaughter of Prince Chakrabongse. British Library, Or. I 5749/I I .6. 


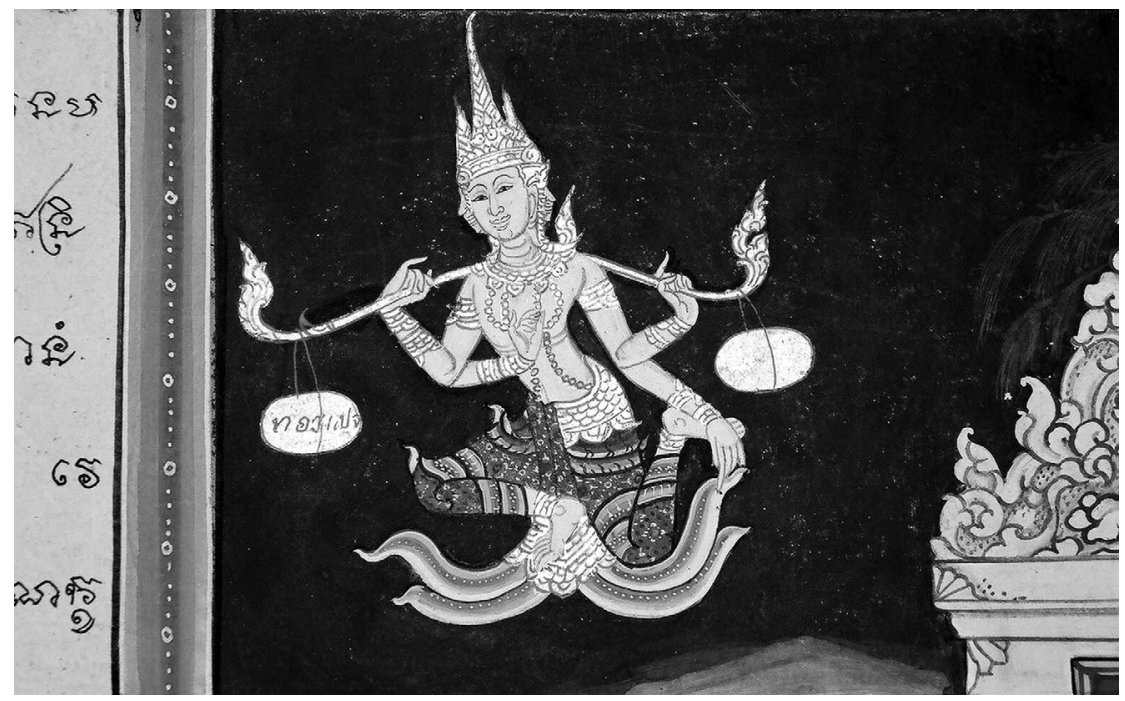

Fig. 3. Detail from a finely illustrated Phra Malai manuscript in Cambodian Mul script, I9th century; acquired by the British Library in memory of Henry D. Ginsburg. British Library, Or. I6552.

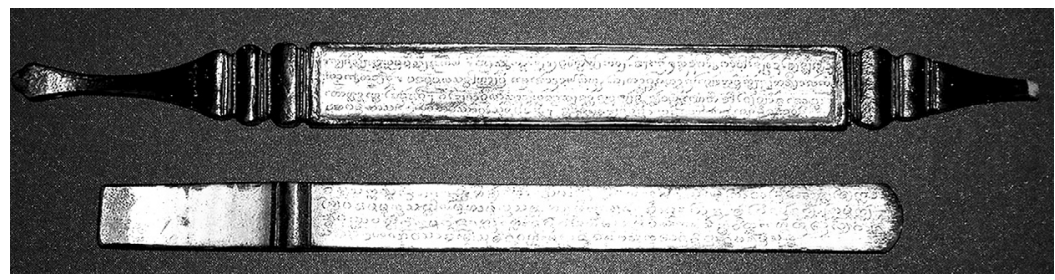

Fig. 4. Two wood and gilt title indicators for Thai manuscripts, from Henry Ginsburg's private collection. British Library, Or. I6554 \& Or. I6555. 